Ibrahim, et al/Jurnal Ekonomi Syariah Teori dan Terapan Vol. 6 N0. 5 Mei 2019: 977-992; FAKTOR-FAKTOR YANG MEMPENGARUHI STRUKTUR MODAL PADA PERUSAHAAN SEKTOR PROPERTI YANG TERDAFTAR DI INDEKS SAHAM SYARIAH INDONESIA (ISSI) PERIODE 2015-2017

FAKTOR-FAKTOR YANG MEMPENGARUHI STRUKTUR MODAL PADA PERUSAHAAN SEKTOR PROPERTI YANG TERDAFTAR DI INDEKS SAHAM SYARIAH INDONESIA (ISSI) PERIODE 2015-20171

Wahyu Maulana Ibrahim

Departemen Ekonomi Syariah- Fakultas Ekonomi dan Bisnis-Universitas Airlangga Email: wahyu.m.i-11@feb.unair.ac.id

\title{
Ari Prasetyo
}

Departemen Ekonomi Syariah- Fakultas Ekonomi dan Bisnis-Universitas Airlangga Email:ari.prasetyo@feb.unair.ac.id

\begin{abstract}
:
This study aims to determine the effect of Tangibility, Profitability, Liquidity, and Company Size on Capital Structure of Property and Real Estate Companies listed in Indonesia Sharia Stock Index in 2015-2017 partially or simultaneously. The approach used is a quantitative approach by using multiple linear regression analysis techniques which then the results are interpreted. The sample used in this research are 31 property and real estate companies listed in Indonesia Sharia Stock Index that meet the criteria of purposive sampling with observation period starting from 2015 until 2017. The results showed that Tangibility, Profitability, Liquidity, and Company Size variables simultaneously and significantly affect the Capital Structure of property and real estate companies listed in Indonesia Sharia Stock Index in 2015-2017. While the partial variable of Tangibility and Liquidity have positive and insignificant effect, Profitability variable has negative and significant effect, and Company Size variable have positive and significant effect to Capital Structure of property and real estate companies listed in Indonesia Sharia Stock Index in 2015-2017.
\end{abstract}

Keywords: Tangibility, Profitability, Liquidity, Company Size, Capital Structure

\section{PENDAHULUAN}

\section{Latar Belakang}

Perkembangan kegiatan ekonomi

di Indonesia tiap waktu terus mengalami peningkatan baik secara kualitas maupun kuantitas. Hal ini dapat dilihat dari pembangunan yang begitu masif terjadi di kota besar maupun di pedesaan. Selain pertumbuhan ekonomi yang terus meningkat, jumlah penduduk di Indonesia juga tiap tahun mengalami peningkatan. Sehingga kebutuhan tempat tinggal akan menjadi keharusan untuk dimiliki oleh setiap penduduk, hal ini memunculkan demand yang cukup besar bagi perusahaan properti.
Permintaan akan produk properti menjadikan perkembangan investasi properti di Indonesia tiap tahun mengalami peningkatan, hal ini dikarenakan investasi properti cukup menjanjikan dan produk investasi yang ditawarkan beraneka ragam. Iklim investasi yang baik ini didukung oleh suku bunga yang rendah dan didukung besarnya permintaan pasar terhadap beragam produk tersebut. Setiap tahun harga tanah di Indonesia meningkat antara 15-20 persen, bahkan di Jakarta mencapai 33 persen per tahun (kompas.com). Selain hunian, perumahan dan apartemen, juga terdapat produk

\footnotetext{
${ }^{1}$ Jurnal ini merupakan bagian dari skripsi dari Wahyu Maulana Ibrahim, NIM: 041114090 , yang diuji pada tanggal 24 Juli 2018.
} 
Ibrahim, et al/Jurnal Ekonomi Syariah Teori dan Terapan Vol. 6 N0. 5 Mei 2019: 977-992; FAKTOR-FAKTOR YANG MEMPENGARUHI STRUKTUR MODAL PADA PERUSAHAAN SEKTOR PROPERTI YANG TERDAFTAR DI INDEKS SAHAM SYARIAH INDONESIA (ISSI) PERIODE 2015-2017

properti berupa gedung perkantoran dan ruko yang juga tumbuh pesat. Hal ini dapat dilihat dari pembangunan gedunggedung perkantoran baru di kawasan bisnis dan pembangunan ruko di sepanjang jalan-jalan utama di kota besar di Indonesia.

Struktur modal dalam penelitian ini diproksikan dengan long term debt to equity ratio (LT.DER). Dari data laporan keuangan perusahaan yang telah diolah menunjukkan terjadi kenaikan dan penurunan struktur modal yang berbedabeda pada masing-masing perusahaan pada tahun 2016 dan 2017. Hal ini perlu dilakukan penelitian untuk mengetahui faktor apa saja yang mempengaruhi struktur modal.

Berdasarkan penelitian sebelumnya yang memiliki hasil yang berbeda dan berdasarkan teori pecking order dan teori trade-off yang saling bertentangan maka dalam penelitian kali ini penulis akan memasukkan variabel independen yang terdiri dari: tangibility, profitability, liquidity dan ukuran perusahaan. Sedangkan variabel dependennya adalah struktur modal perusahaan properti yang terdaftar di ISSI.

\section{Rumusan Masalah}

1. Apakah tangibility berpengaruh secara parsial terhadap struktur modal perusahaan properti yang terdaftar dalam Indeks Saham Syariah Indonesia (ISSI) periode 2015-2017?

2. Apakah profitability berpengaruh secara parsial terhadap struktur modal perusahaan properti yang terdaftar dalam Indeks Saham Syariah Indonesia (ISSI) periode 2015-2017?

3. Apakah liquidity berpengaruh secara parsial terhadap struktur modal perusahaan properti yang terdaftar dalam Indeks Saham Syariah Indonesia (ISSI) periode 2015-2017?

4. Apakah ukuran perusahaan berpengaruh secara parsial terhadap struktur modal perusahaan properti yang terdaftar dalam Indeks Saham Syariah Indonesia (ISSI) periode 2015$2017 ?$

5. Apakah tangibility, profitability, liquidity, dan ukuran perusahaan berpengaruh secara simultan terhadap struktur modal perusahaan properti yang terdaftar dalam Indeks Saham Syariah Indonesia (ISSI) periode 2015-2017?

\section{Tujuan Penelitian}

1. Untuk mengetahui pengaruh tangibility secara parsial terhadap struktur modal perusahaan properti yang terdaftar dalam Indeks Saham Syariah Indonesia (ISSI) periode 2015-2017.

2. Untuk mengetahui pengaruh profitability secara parsial terhadap struktur modal perusahaan properti yang terdaftar dalam Indeks Saham Syariah Indonesia (ISSI) periode 20152017.

3. Untuk mengetahui pengaruh liquidity secara parsial terhadap struktur modal perusahaan properti yang terdaftar dalam Indeks Saham Syariah Indonesia (ISSI) periode 2015-2017. 
4. Untuk mengetahui pengaruh ukuran perusahaan secara parsial terhadap struktur modal perusahaan properti yang terdaftar dalam Indeks Saham Syariah Indonesia (ISSI) periode 20152017.

5. Untuk mengetahui pengaruh tangibility, profitability, liquidity, dan ukuran perusahaan secara simultan terhadap struktur modal perusahaan properti yang terdaftar dalam Indeks Saham Syariah Indonesia (ISSI) periode 20152017.

\section{TINJAUAN PUSTAKA}

\section{Struktur Modal}

Struktur modal merupakan
masalah yang penting dalam pengambilan keputusan mengenai pembelanjaan perusahaan karena secara langsung berpengaruh terhadap biaya modal, keputusan capital budgeting, dan harga pasar. Menurut Halim (2007 : 58) struktur modal menunjukkan perimbangan jumlah utang jangka pendek yang bersifat tetap, utang jangka panjang, saham preferen, dan saham biasa. Sedangkan dalam Alwi (1991 : 299) struktur modal ditentukan oleh perbandingan antara hutang jangka panjang dan modal sendiri yang digunakan oleh perusahaan.

\section{Teori Struktur Modal}

Teori ilmiah tentang struktur modal diawali oleh dua orang ahli manajemen kevangan yaitu Franco Modigliani dan Merton Miller pada tahun 1958. Berdasarkan serangkaian asumsi yang sangat membatasi, MM membuktikan bahwa nilai suatu perusahaan tidak dipengaruhi oleh struktur modalnya. (Brigham dan Houston, 2001: 31).

Selanjutnya ada Teori MM dengan pajak pada tahun 1963, sekaligus melemahkan teori sebelumnya yang tidak mempehitungkan pajak perseroan. Peraturan perpajakan memperbolehkan pengurangan pembayaran bunga sebagai beban, tetapi pembayaran dividen kepada pemegang saham tidak dapat dikurangkan. Menurut Brigham dan Houston (2001:32) perlakuan yang berbeda ini mendorong perusahaan untuk menggunakan hutang pada struktur modalnya.

Model trade-off menurut Atmaja (2008) merupakan model MM dengan pajak yang mempertimbangkan financial distress dan agency cost. Trade-off theory mempunyai makna bahwa manajer akan berpikir dalam kerangka trade-off antara penghematan pajak dan biaya kesulitan keuangan dalam penentuan struktur modal (Puji, 2016:30). Trade-off theory telah memberikan konstribusi yang besar tentang pertimbangan antara biaya dan keuntungan dari penggunaan hutang. Perusahaan-perusahaan dengan tingkat profitabilitas tinggi tentu akan berusaha mengurangi pajaknya dengan cara meningkatkan rasio hutangnya, sehingga tambahan hutang tersebut akan mengurangi pajak.

Pecking order theory dikembangkan oleh Stewart C. Myers dan 
Ibrahim, et al/Jurnal Ekonomi Syariah Teori dan Terapan Vol. 6 N0. 5 Mei 2019: 977-992; FAKTOR-FAKTOR YANG MEMPENGARUHI STRUKTUR MODAL PADA PERUSAHAAN SEKTOR PROPERTI YANG TERDAFTAR DI INDEKS SAHAM SYARIAH INDONESIA (ISSI) PERIODE 2015-2017

Nicolas Majluf pada tahun 1984. Menurut Brearley dan Myers (2003) teori pecking order diawali dengan kehadiran informasi yang tidak simetrik antara manajer dan investor. Manajer memiliki informasi yang lebih banyak daripada investor mengenai keadaan perusahaan. Informasi ini mempengaruhi pilihan antara pembiayaan internal dan eksternal.Dalam pecking order theory ini tidak terdapat stuktur modal optimal. Dengan demikian, perusahaan akan lebih memilih membiayai investasinya berdasarkan urutan resiko

\section{Tangibility}

Tangibility berhubungan dengan aset tetap yang dimiliki perusahaan. Aset tetap merupakan bagian dari neraca yang dilaporkan dalam setiap periode atau setiap tahun. Aset ini digolongkan menjadi aset tetap berwujud (tangiable fixed assets) dan aset tetap tidak berwujud (intangiable assets). Aset tetap adalah aset berwujud yang diperoleh dalam bentuk siap pakai atau dibangun terlebih dahulu, yang digunakan dalam operasi perusahaan, tidak dimaksudkan untuk dijual dalam rangka kegiatan normal perusahaan dan mempunyai masa manfaat lebih dari satu tahun (PSAK No. 16 Tahun 2007).

\section{Profitability}

Profitabilitas menurut Hapsari
(2010) merupakan kemampuan perusahaan dalam memperoleh laba, semakin tinggi kemampuan perusahaan dalam memperoleh laba, maka semakin besar pula return yang diharapkan investor. Sedangkan menurut Libby, et al. (2008:708) profitabilitas merupakan alat ukur kesuksesan sebuah perusahaan yang utama dan profitabilitas penting untuk kelangsungan hidup perusahaan.

\section{Liquidity}

Likuiditas menurut Libby, et al. (2008:720) mengacu pada kemampuan perusahaan untuk memenuhi hutang yang jatuh tempo saat ini. Sedangkan rasio likuditas menurut Harahap (2009:317) menggambarkan

kemampuan perusahaan untuk menyelesaikan kewajiban jangka pendeknya. Rasio-rasio ini dapat dihitung melalui sumber informasi tentang modal kerja, yaitu pos-pos aktiva lancar dan utang lancar.

\section{Ukuran Perusahaan}

Ukuran perusahaan menurut Sudarmadji dan Sularto (2007) dapat dinyatakan dalam total aktiva, penjualan dan kapitalisasi pasar. Ketiga variabel ini dapat digunakan untuk menentukan ukuran perusahaan. Semakin besar total aktiva yang dimiliki perusahaan berarti semakin besar pula modal yang ditanam dalam perusahaan, demikian pula dengan penjualan yang berarti semakin banyak penjualan maka semakin banyak perputaran vang, dan kapitalisasi pasar yang besar akan semakin dikenal perusahaan dalam masyarakat.

Hubungan Tangibility dengan Struktur
Modal
Tangibility berhubungan dengan
aset tetap yang dimiliki perusahaan. Aset


Ibrahim, et al/Jurnal Ekonomi Syariah Teori dan Terapan Vol. 6 N0. 5 Mei 2019: 977-992; FAKTOR-FAKTOR YANG MEMPENGARUHI STRUKTUR MODAL PADA PERUSAHAAN SEKTOR PROPERTI YANG TERDAFTAR DI INDEKS SAHAM SYARIAH INDONESIA (ISSI) PERIODE 2015-2017

tetap dapat berupa properti, mesin, dan kendaraan yang dapat dijadikan sebagai jaminan, jaminan diperlukan dalam pengajuan kredit karena dianggap dapat mengurangi resiko yang ditanggung kreditur. Jadi semakin besar asset tangibility yang dimiliki perusahaan, maka kreditur akan lebih mudah memberi pinjaman sehingga tingkat utang perusahaan menjadi besar. Menurut Brigham et. al (1999) dalam Wardhana (2012), secara umum perusahaan yang memiliki jaminan terhadap hutang akan lebih mudah mendapatkan hutang daripada perusahaan yang tidak memiliki jaminan. Oleh karena itu, perusahaan yang memiliki jaminan atau asset tangibility yang besar akan cenderung memiliki hutang yang besar juga. Perusahaan dengan asset tangibility yang besar dianggap mampu untuk memenuhi kewajibannya termasuk kewajiban yang berupa hutang.

\section{Hubungan Profitability terhadap Struktur Modal}

Brigham dan Houston (2001:357) mengatakan bahwa perusahaan dengan tingkat pengembalian yang tinggi atas investasi akan menggunakan utang relatif kecil. Hal ini didukung dengan teori pecking order yang menyatakan bahwa perusahaan dengan tingkat profitabilitas yang tinggi justru tingkat hutangnya rendah, dikarenakan perusahaan dengan profitabilitas tinggi memiliki sumber dana internal yang melimpah (Myers, 2001). Terdapat hubungan yang negatif antara profitabilitas dengan hutang. Pada tingkat profitabilitas yang rendah, perusahaan akan menggunakan hutang untuk membiayai operasional, sebaliknya pada tingkat profitabilitas yang tinggi perusahaan akan mengurangi penggunaan hutang. Hal ini disebabkan saat perusahaan memiliki tingkat profitabilitas yang tinggi akan memiliki laba ditahan yang besar juga, sehingga perusahaan lebih menyukai pendanaan internal yang memiliki resiko rendah dibandingkan hutang yang memiliki resiko tinggi.

\section{Hubungan Liquidity terhadap Struktur Modal}

Likuiditas berkaitan dengan kemampuan perusahaan dalam melunasi hutang jangka pendek yang telah jatuh tempo. Current ratio menunjukkan kemampuan perusahaan untuk membayar kewajiban jangka pendeknya menggunakan aktiva lancarnya. Perusahaan dengan tingkat likuditas yang tinggi, berarti mampu melunasi hutang jangka pendeknya dengan baik. Hal ini membuat perusahaan dengan mudah mendapat kepercayaan dari kreditur untuk mendapatkan pinjaman dalam jumlah yang lebih besar. Dengan tingkat current ratio yang tinggi tentu perusahaan tidak merasa kesulitan apabila harus mengambil hutang yang lebih besar. Nugroho (2006) menyatakan bahwa kebutuhan dana untuk aktiva lancar pada prinsipnya dibiayai oleh kredit jangka pendek. Jadi semakin likuid 
Ibrahim, et al/Jurnal Ekonomi Syariah Teori dan Terapan Vol. 6 N0. 5 Mei 2019: 977-992; FAKTOR-FAKTOR YANG MEMPENGARUHI STRUKTUR MODAL PADA PERUSAHAAN SEKTOR PROPERTI YANG TERDAFTAR DI INDEKS SAHAM SYARIAH INDONESIA (ISSI) PERIODE 2015-2017

perusahaan, maka semakin tinggi penggunaan hutangnya.

Hubungan Ukuran Perusahaan terhadap Struktur Modal

Perusahaan besar memiliki kebutuhan dana yang besar dan salah satu alternatif pemenuhan dananya adalah menggunakan dana eksternal. Perusahaan yang besar juga memiliki kemudahan untuk masuk ke pasar modal dibandingkan perusahaan kecil. Sehingga semakin besar ukuran perusahaan maka perusahaan akan cenderung melakukan pendanaan dari luar karena kebutuhan dana mereka juga semakin besar dan ditambah dengan kemudahan yang dimiliki untuk mendapatkan pinjaman.

\section{METODE PENELITIAN}

\section{Jenis dan Pendekatan Penelitian}

Tujuan penelitian ini adalah untuk menjawab rumusan masalah penelitian, yaitu berpengaruh atau tidaknya tangibility, profitability, liquidity, dan ukuran perusahaan terhadap struktur modal perusahaan properti dan real estate yang terdaftar dalam ISSI tahun 2015-2017. Penelitian ini menggunakan pendekatan kuantitatif dengan mengkaji literatur, teori dan penelitian terdahulu yang relevan, sehingga dapat dirumuskan suatu hipotesis. Hipotesis diuji menggunakan analisis atas data-data yang terukur dan dilakukan pengujian. Pengujian mengarah pada hasil yang akurat sehingga dapat diperoleh kesimpulan yang digenealisasikan.

\section{Identifikasi Variabel}

Sesuai dengan rumusan masalah dan model analisisi yang telah dijelaskan sebelumnya, variabel yang akan digunakan dalam penelitian ini terdiri dari empat variabel indipenden dan satu variabel dependen. Variabel-variabel tersebut adalah:

1. Variabel independen (eksogen) terdiri dari tangibility, profitability, liquidity, dan ukuran perusahaan.

2. Variabel dependen (endogen), yaitu struktur modal.

\section{Definisi Operasional}

Definisi operasional dimaksudkan untuk menghindari adanya kesalahpahaman dan penafsiran makna yang berbeda. Definisi tersebut berisi tentang pernyataan pengoperasionalan dan atau pendefinisian konsep-konsep peneliti ini menjadi variabel-variabel penelitian termasuk penetapan cara dan satuan pengukuran variabelnya. Definisi operasional dari variabel-variabel yang digunakan dalam penelitian ini adalah:

1. Tangibility

Tangibility

merupakan perbandingan antara aset tetap dengan total aset yang dimiliki masing-masing perusahaan. Rumus tangibility adalah:

$$
\text { Tangibility }=\frac{\text { Fixed } \text { Assets }}{\text { Total Assets }}
$$

\section{Profitability}

Profitability dalam penelitian ini diproksikan dengan Return on Assets (ROA), ROA diukur dengan membandingkan total laba setelah pajak dari pendapatan yang diperoleh dan 
Ibrahim, et al/Jurnal Ekonomi Syariah Teori dan Terapan Vol. 6 N0. 5 Mei 2019: 977-992; FAKTOR-FAKTOR YANG MEMPENGARUHI STRUKTUR MODAL PADA PERUSAHAAN SEKTOR PROPERTI YANG TERDAFTAR DI INDEKS SAHAM SYARIAH INDONESIA (ISSI) PERIODE 2015-2017

total aktiva masing-masing perusahaan. Rumus Return on Assets (ROA) adalah:

$$
\text { ROA }=\frac{\text { Laba Setelah Pajak }}{\text { Total Aktiva }}
$$

3. Liquidity

Liquidity dalam penelitian ini diprosikan dengan Current Ratio atau Rasio Lancar, Current Ratio diukur dengan membagi aktiva lacar (current assets) dengan hutang lancar (current liabilities). Rumus Cureent Ratio adalah:

$$
\text { Current Ratio }=\frac{\text { Current Assets }}{\text { Current Liabilities }}
$$

4. Ukuran Perusahaan

Ukuran perusahaan merupakan ukuran besar atau kecilnya perusahaan berdasarkan total aset. Ukuran perusahaan diukur dengan menggunakan rumus:

Ukuran Perusahaan $=\mathrm{Ln}$ Total Aset

5. Struktur Modal

Struktur modal merupakan keputusan keuangan perusahaan yang berkaitan dengan hutang, saham preferen dan saham biasa yang digunakan perusahaan dalam pembiayaan operasionalnya. Menurut Alwi (1991 : 299) struktur modal ditentukan oleh perbandingan antara hutang jangka panjang dan modal sendiri yang digunakan oleh perusahaan. Struktur modal dalam penelitian ini diproksikan dengan Long Term Debt to Equity Ratio (LT DER). Rumus dari Long Term Debt to Equity Ratio adalah:

LT DER $=\frac{\text { Hutang Jangka Panjang }}{\text { Modal Sendiri }}$

\section{Jenis dan Sumber Data}

Jenis data yang digunakan dalam penelitian ini adalah data sekunder. Data sekunder yang digunakan dalam penelitian ini berupa data laporan keuangan tahunan dan company report perusahaan property dan real estate yang terdaftar dalam ISSI periode tahun 2015 sampai dengan 2017 yang diperoleh dari website BEl.

Populasi

Populasi adalah himpunan keseluruhan karakteristik objek yang diteliti (Sedarmayanti dan Hidayat, 2002:121). Populasi merupakan obyek atau subyek yang memiliki karakteristik tertentu yang ditetapkan oleh peneliti, populasi masih terbilang cukup luas cakupannya sebelum selanjutnya dilakukan pengambilan sampel dari anggota populasi yang mewakili keseluruhan anggota populasi. Populasi yang digunakan dalam penelitian ini adalah perusahaan property dan real estate yang terdaftar dalam ISSI periode 2015 sampai dengan 2017.

\section{Sampel}

Metode pemilihan sampel yang digunakan dalam penelitian ini adalah purposive sampling. Dalam purposive sampling, pertimbangan peneliti memegang peranan, bahkan dalam pengambilan sekumpulan objek untuk diteliti (Sedarmayanti dan Hidayat, 2002:131). Sampel yang digunakan dalam penelitian ini adalah anggota dari populasi yang telah disesuaikan dengan 
Ibrahim, et al/Jurnal Ekonomi Syariah Teori dan Terapan Vol. 6 N0. 5 Mei 2019: 977-992; FAKTOR-FAKTOR YANG MEMPENGARUHI STRUKTUR MODAL PADA PERUSAHAAN SEKTOR PROPERTI YANG TERDAFTAR DI INDEKS SAHAM SYARIAH INDONESIA (ISSI) PERIODE 2015-2017

kriteria tertentu sesuai tujuan dari penelitian. Kriteria tersebut adalah:

1. Terdaftar sebagai perusahaan property dan real estate yang terdaftar tetap di Indeks Saham Syariah Indonesia (ISSI) periode 2015 sampai dengan 2017.

2. Perusahaan yang menerbitkan company report dan laporan tahunan pada tahun 2015 sampai dengan 2017.

Proses pengumpulan data yang dilakukan dalam penelitian ini melalui tahap-tahap berikut:

1. Tahap pertama dilakukan studi kepustakaan dengan mengumpulkan teori-teori yang pendukung dari literatur dan penelitian terdahulu.

2. Tahap kedua adalah pengumpulan data-data sekunder yang diperlukan, yaitu data perusahaan property dan real estate yang terdaftar tetap di Indeks Saham Syariah Indonesia (ISSI) periode 2015 sampai dengan 2017, data laporan keuangan dan company report yang diterbitkan oleh $\mathrm{BEI}$.

\section{Pengujian Penyimpangan Asumsi Klasik}

Uji penyimpangan asumsi klasik dilakukan untuk mengetahui beberapa penyimpangan yang terjadi pada data yang digunakan untuk penelitian. Model regresi dapat disebut sebagai model yang baik jika memenuhi kriteria BLUE (Best Linier Unbiased Estimator). BLUE dapat dicapai bila memenuhi uji asumsi klasik. Asumsi klasik yang digunakan dalam penelitian ini yaitu: uji normalitas, multikolinearitas, heteroskedastisitas dan autokorelasi.

\section{Uji Normalitas}

Uji normalitas bertujuan untuk mengetahui apakah dalam model regresi, distribusi dalam sebuah data variabel dependen dan variabel independen keduanya mengikuti atau mendekati distribusi normal ataukah tidak. Model regresi yang baik adalah memiliki pola seperti distribusi data normal atau mendekati normal, yakni distribusi data tersebut tidak menceng ke kiri atau menceng ke kanan (Santoso, 2010:43) dalam (Mauluda, 2016:66).

\section{Uji Multikolinearitas}

Uji multikolinearitas adalah untuk melihat ada atau tidaknya korelasi yang tinggi antara variabel-variabel bebas dalam suatu model regresi linear berganda. Hubungan antara variabel bebas terhadap variabel terikatnya menjadi terganggu, jika ada korelasi yang tinggi di antara variabel-variabel bebasnya. (Sutopo dan Slamet, 2017:107). Model regresi yang baik seharusnya tidak terjadi multikolinearitas.

\section{Uji Heteroskedastisitas}

Menurut Nisfiannoor (2009:92), uji heteroskedastisitas dilakukan untuk mengetahui apakah sebuah data (group) mempunyai variansi yang sama atau berbeda di antara data (group) tersebut. Data yang diharapkan adalah yang memiliki variansi sama, dan disebut homoskedastisitas. Sedangkan jika variansi tidak sama, disebut heteroskedastisitas. 
Ibrahim, et al/Jurnal Ekonomi Syariah Teori dan Terapan Vol. 6 N0. 5 Mei 2019: 977-992; FAKTOR-FAKTOR YANG MEMPENGARUHI STRUKTUR MODAL PADA PERUSAHAAN SEKTOR PROPERTI YANG TERDAFTAR DI INDEKS SAHAM SYARIAH INDONESIA (ISSI) PERIODE 2015-2017

\section{Uji Autokorelasi}

Uji ini bertujuan untuk mengetahui apakah ada korelasi antara suatu periode † dengan periode sebelumnya (t-1) (Sutopo, 2017:102). Uji autokorelasi hanya dilakukan pada data time series dan tidak perlu dilakukan pada data cross section seperti pada kuisioner dimana pengukuran semua variabel dilakukan secara bersamaan. Model regresi pada penelitian data laporan tahunan di BEI dimana periodenya lebih dari satu tahun biasanya memerlukan autokorelasi. Model regresi yang baik adalah yang bebas dari autokorelasi. Untuk menguji keberadaan autokorelasi dalam penelitian ini digunakan Durbin-Watson test.

\section{Pengujian Hipotesis}

Dalam penelitian ini tangibility, profitability, liquidity, dan ukuran perusahaan digunakan sebagai variabel eksogen (independen). Sedangkan struktur model sebagai variabel endogen (dependen). Teknik analisis yang digunakan adalah analisis regresi linear berganda untuk melihat hubungan parsial dan simultan antara tangibility, profitability, liquidity, dan ukuran perusahaan terhadap struktur modal. Persamaan regersi linear berganda dalam penelitian ini, adalah:

$$
\text { LT DER }=a+\beta_{1} \text { Tangibility }+\beta_{2} R O A+
$$

$\beta_{3} C R+\beta_{4}$ Size $+e$

Keterangan:

$a=$ konstanta

$\beta_{1}, \beta_{2}, \beta_{3}, \beta_{4}=$ slope yang berhubungan dengan variabel independen
LT DER = rasio hutang jangka panjang dengan modal sendiri

Tangibility $=$ perbandingan antara aset tetap dengan total aset

$\mathrm{ROA}=$ rasio profitabilitas (Return on Assets)

$\mathrm{CR}=$ rasio likuiditas (Current Ratio)

Size $=$ ukuran Perusahaan

$\mathrm{e}=$ variabel residual

Data-data yang telah diperoleh, selanjutnya dilakukan regresi. Regresi antar variabel menggunakan alat bantu statistika.

\section{Uji Signifikansi}

Melakukan uji t, untuk melihat pengaruh variabel bebas secara parsial terhadap variabel terikat.

\section{Koefisien Determinasi}

Koefisien determinasi $\left(R^{2}\right)$ pada intinya mengukur seberapa jauh kemampuan model dalam menerangkan variasi variabel dependen.

Uji F

Melakukan uji $F$, untuk melihat pengaruh variabel bebas terhadap variabel terikat secara simultan.

IV. HASIL DAN PEMBAHASAN

Analisis data diperlukan sehingga tujuan dari penelitian ini dapat tercapai. Analisis data yang digunakan dalam penelitian ini adalah menggunakan regresi linear berganda yang sebelumnya dilakukan terlebih dahulu adalah melakukan uji asumsi klasik yang terdiri dari uji normalitas, uji multikolinearitas, uji heteroskedastisitas, dan uji autokorelasi. Penelitian ini menggunakan alat uji statistic IBM SPSS 22 untuk melakukan 
analisis dari data yang telah diolah sebelumnya.

\section{Uji Normalitas}

Uji normalitas menurut Latan (2014:171) dapat dilakukan melalui SPSS dengan cara melihat grafik histogram maupu grafik P-P plot. Pengujian normalitas menggunakan grafik histogram untuk variabel dependen struktur modal (LTD.ER) dapat dilihat pada gambar 1 berikut ini:

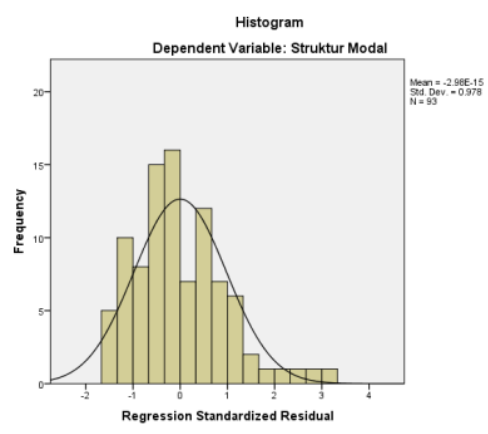

Sumber: Hasil Uji Normalitas Grafik Histogram (data diolah)

Gambar 1,

Uji Normalitas Data untuk Struktur Modal

\section{Menggunakan Grafik Histogram}

Berdasarkan grafik histogram pada

Gambar 1 dapat dilihat bahwa terjadi pola berbentuk lonceng dan sebaran data yang mendekati garis normal sehingga dapat dismpulkan bahwa data menggunakan variabel dependen struktur modal telah terdistribusi secara normal.

Deteksi lain yang bisa mendeteksi distribusi normal adalah menggunakan uji Normal Probabiity Plot atau biasa disebut P-P Plot. Grafik P-P plot untuk variabel dependen struktur modal (LTD.ER) dapat dilihat pada Gambar 2:

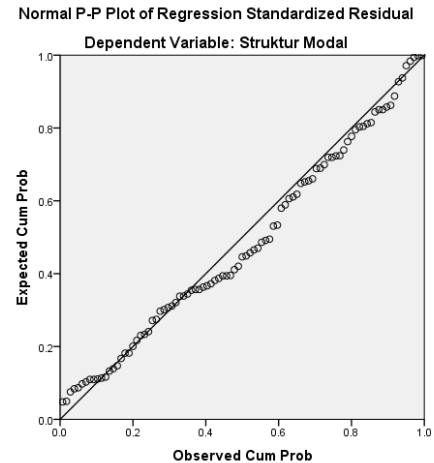

Sumber: Hasil Uji Normalitas P-P Plot (data diolah)

\section{Gambar 2.}

Uji Normalitas Data untuk Struktur Modal (LTD.ER) sebagai Variabel Dependen dengan Grafik P-P Plot

Gambar 2 menunjukkan bahwa uji Normalitas melalui grafik P-P Plot untuk variabel struktur modal (LTD.ER) telah terdistribusi secara normal karena titik-titik pada grafik masih enyebar disekitar garis diagonal. Sehingga dapat disimpulkan bahwa data penelitian ini telah memenuhi asumsi normalitas.

\section{B. Uji Multikolinearitas}

Uji multikolinearitas dengan variabel dependen struktur modal, dapat dilihat pada Tabel 1:

Tabel 1.

\section{Nilai VIF dan Tolerance}

Nilai VIF dan Tolerance Struktur Modal sebagai Variabel Dependen

\begin{tabular}{|c|c|c|c|}
\hline \multirow[b]{2}{*}{ Mode } & & \multicolumn{2}{|c|}{ Collinearity Statistics } \\
\hline & & Tolerance & VIF \\
\hline \multirow[t]{5}{*}{1} & (Constant) & & \\
\hline & Tangibility & .972 & 1.029 \\
\hline & Profitability & .969 & 1.032 \\
\hline & Liquidity & .873 & 1.145 \\
\hline & Ukuran Perusahaan & .906 & 1.104 \\
\hline
\end{tabular}

Sumber: Hasil Uji VIF (data diolah) 
Ibrahim, et al/Jurnal Ekonomi Syariah Teori dan Terapan Vol. 6 N0. 5 Mei 2019: 977-992; FAKTOR-FAKTOR YANG MEMPENGARUHI STRUKTUR MODAL PADA PERUSAHAAN SEKTOR PROPERTI YANG TERDAFTAR DI INDEKS SAHAM SYARIAH INDONESIA (ISSI) PERIODE 2015-2017

Berdasarkan Tabel 1, nilai Variance Inflation Factor (VIF) yang diperoleh untuk Tangibility adalah 1.029, profitability memperoleh nilai sebesar 1.032, Liquidity sebesar 1.145, dan Ukuran Perusahaansebesar 1.104. Nilai Variance Inflation Factor (VIF) dari keempat variabel tersebut lebih dari 1 dan kurang dari 10 sehingga berada direntang dimana dikatakan tidak terdapat multikolinearitas. Hasil yang sama juga ditunjukkan oleh nilai tolerance yang jauh dari nol dan hampir mendekati satu, sehingga dikatakan bahwa data pada pelitian ini tidak mengalami multikolinearitas. Hal itu dibuktikan dari hasil tolerance untuk Tangibility sebesar 0.971, profitability sebesar 0.969 , liquidity sebesar 0.873 , dan ukuran perusahaansebesar 0.906. Maka dapat disimpulkan bahwa dalam penelitian ini tidak terjadi kolinearitas yang artinya tidak terdapat hubungan berkorelasi tinggi antar variabel bebas sehingga hubunga variabel bebas dan variabel terikat tidak akan terganggu.

\section{Uji Heteroskedastisitas}

Uji heteroskedastisitas dalam penelitian ini dapat dilihat dalam gambar 4 berikut ini:

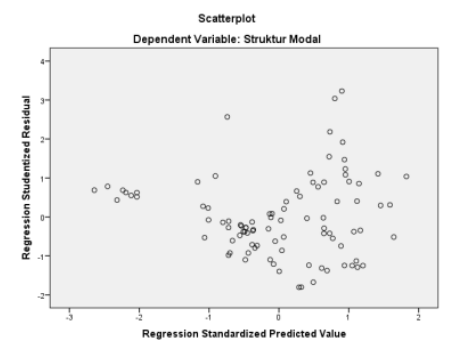

Sumber: Hasil Uji Scatterplot (data diolah)

Gambar 3.

Scatterplot Uji Heteroskedastisitas
Dengan melihat grafik scatterplot pada gambar 3 diketahui bahwa tidak terjadi heterokedastisitas di antara variabel dalam penelitian ini. Hal ini dapat dibuktikan dengan titik titik yang tidak berpola dan menyebar di sekitar angka 0 pada sumbu $Y$.

\section{Uji Autokorelasi}

Uji autokorelasi perlu dilakukan pada data time series, uji ini menurut Sutopo (2017:102) bertujuan untuk mengetahui ada tidaknya korelasi antar sampel pada periode $\dagger$ dengan periode $\dagger$ sebelumnya. Pengujian autokorelasi dalam penelitian ini menggunakan uji Durbin-Watson (DW), penentuan ada tidaknya autokorelasi dapat dilihat dengan menggunakan Gambar 3 pada bab 3 yang menjelaskan bahwa jika nilai DW berada di antara dU dan 4-dU maka tidak terjadi autokorelasi.

Pengujian Durbin-Watson dalam penelitian ini yaitu dengan menentukan nilai batas bawah (dL) dan batas atau (dU). Pada $(a)=5 \%, k=4$, dan $n=93$ maka diketahui $\mathrm{dL}=1,5471$ dan $\mathrm{dU}=1,7531$.

Hasil uji Durbin-Watson yang dilakukan ternyata memunculkan nilai DW yang berada di antara $\mathrm{dL}$ dan $\mathrm{dU}$ sehingga masih belum bisa disimpulkan atau terjadi keragu-raguan antara terjadi autokorelasi atau tidak. Karena belum dapat disimpulkan maka perlu dilakukan uji autokorelasi yang lain yaitu uji run test. Uji run test dalam penelitian ini dapat dilihat dalam tabel 2: 
Uji Run Test

Tabel 2.

Hasil Uji Run Test

\begin{tabular}{|l|l|}
\hline & $\begin{array}{l}\text { Unstandardize } \\
\text { d Residual }\end{array}$ \\
\hline Test Valuea & -.03228 \\
Cases < Test Value & 46 \\
Cases >= Test Value & 47 \\
\hline Total Cases & 93 \\
Number of Runs & 46 \\
$z$ & -.312 \\
\hline Asymp. Sig. (2-tailed) & .755 \\
\hline
\end{tabular}

Sumber: Uji Run Test (data diolah)

Hasil uji run test menunjukkan bahwa nilai Asymp.Sig. (2-tailed) > 0.05 yang berarti bahwa data yang dipergunakan dalam penelitian ini cukup random (acak) sehingga dapat disimpulkan bahwa data yang akan diuji tidak terjadi autokorelasi.

\section{Koefisien Determinasi $\left(\mathbf{R}^{2}\right)$ dan adjusted $\mathbf{R}^{\mathbf{2}}$}

Nilai koefisien determinasi $\left(R^{2}\right)$ sebesar 0.425 atau $42.5 \%$ artinya variabelvariabel independen tangibility, profitability, liquidity, dan ukuran perusahaan mampu menjelaskan variabel dependen sebesar $42.5 \%$ dan sisanya 57.5 \% dijelaskan oleh variabel lain di luar model penelitian.

\section{Analisis Regresi Linear Berganda}

Hasil Regresi

Persamaan untuk regresi linier berganda dalam penelitian ini dapat ditulis sebagai berikut:

LTD.ER $=a+\beta_{1}$ Tangibility $+\beta_{2} R O A+\beta_{3} C R+$ $\beta_{4}$ Size $+e_{1}$
LTD.ER $=-3.323+0.002$ Tangibility $0.009 R O A+0.002 C R+0.128$ Size

Konstanta sebesar -3.323 dapat diartikan bahwa rata-rata LTD.ER pada perusahaan properti dan real estate yang terdaftar dalam ISSI periode 2015-2017 adalah sebesar -3.323 dengan asumsi tangibility, ROA, $C R$, dan size tidak mengalami perubahan. Kostanta bernilai 3.323 menunjukkan bahwa ketika tangibility, ROA, CR, dan Size bernilai nol maka LTD.ER atau struktur modal memiliki nilai -3.323.

ROA mempunyai pengaruh negatif terhadap struktur modal artinya apabila ROA mengalami peningkatan maka struktur modal mengalami penurunan nilai. Dengan koefisien regresi sebesar -0.009 maka apabila ROA naik sebesar satu satuan, maka struktur modal (LTD.ER) akan mengalami penurunan sebesar -0.009. sedangkan untuk variabel independen yang lainnya memiliki pengaruh yang positif atau searah dengan struktur modal. Apabila tangibility, profitability dan size naik satu satuan, maka struktur modal juga naik sebesar koefisen regresi tangibility, profitability, dan size.

\section{Uji Signifikan Parsial (Uji t)}

Tabel 3.

\section{Rangkuman Hasil Uji †}

\begin{tabular}{|c|c|c|c|c|}
\hline $\begin{array}{l}\text { Variabel } \\
\text { Independen }\end{array}$ & $\begin{array}{l}\text { Nilai } \dagger \\
\text { Hitun } \\
g\end{array}$ & (a) & Sig. & $\begin{array}{l}\text { Keteranga } \\
\mathrm{n}\end{array}$ \\
\hline Tangibility & $\begin{array}{l}0.01 \\
8\end{array}$ & $\begin{array}{l}0.0 \\
5\end{array}$ & $\begin{array}{l}0.98 \\
6\end{array}$ & $\begin{array}{l}\text { Sig }>a \\
\text { maka HO }\end{array}$ \\
\hline
\end{tabular}


Ibrahim, et al/Jurnal Ekonomi Syariah Teori dan Terapan Vol. 6 N0. 5 Mei 2019: 977-992; FAKTOR-FAKTOR YANG MEMPENGARUHI STRUKTUR MODAL PADA PERUSAHAAN SEKTOR PROPERTI YANG TERDAFTAR DI INDEKS SAHAM SYARIAH INDONESIA (ISSI) PERIODE 2015-2017

\begin{tabular}{|c|c|c|c|c|}
\hline & & & & diterima \\
\hline Profitability & $\begin{array}{l}- \\
2.35 \\
8\end{array}$ & $\begin{array}{l}0.0 \\
5\end{array}$ & $\begin{array}{l}0.02 \\
1\end{array}$ & $\begin{array}{l}\text { Sig }<a \\
\text { maka HO } \\
\text { ditolak }\end{array}$ \\
\hline $\begin{array}{l}\text { Variabel } \\
\text { Independen }\end{array}$ & $\begin{array}{l}\text { Nilai } \dagger \\
\text { Hitun } \\
\mathrm{g}\end{array}$ & (a) & Sig. & $\begin{array}{l}\text { Keteranga } \\
\mathrm{n}\end{array}$ \\
\hline Liquidity & $\begin{array}{l}0.17 \\
6\end{array}$ & $\begin{array}{l}0.0 \\
5\end{array}$ & $\begin{array}{l}0.86 \\
1\end{array}$ & $\begin{array}{l}\text { Sig }>\text { a } \\
\text { maka HO } \\
\text { diterima }\end{array}$ \\
\hline $\begin{array}{l}\text { Ukuran } \\
\text { Perusahaa } \\
\mathrm{n}\end{array}$ & $\begin{array}{l}7.54 \\
8\end{array}$ & $\begin{array}{l}0.0 \\
5\end{array}$ & $\begin{array}{l}0.00 \\
0\end{array}$ & $\begin{array}{l}\text { Sig }<a \\
\text { maka HO } \\
\text { ditolak }\end{array}$ \\
\hline
\end{tabular}

Sumber: Hasil Uji † (data diolah)

Berdasarkan Tabel 3 di atas, diperoleh hasil sebagai berikut:

a. Variabel tangibility mempunyai signifikansi sebesar $0.986>$ a maka dapat disimpulkan $\mathrm{H}_{0}$ diterima sehingga tangibility berpengaruh tidak signifikan secara positif terhadap struktur modal (LTD.ER).

b. Variabel profitability mempunyai signifikansi sebesar0.021 < a maka dapat disimpulkan $\mathrm{H}_{0}$ ditolak sehingga profitability berpengaruh signifikan secara negative terhadap struktur modal (LTD.ER).

C. Variabel liquidity mempunyai signifikansi sebesar $0.861>a$ maka dapat disimpulkan $\mathrm{H}_{0}$ diterima sehingga liquidity berpengaruh tidak signifikan secara positif terhadap struktur modal (LTD.ER).

d. Varibel ukuran perusahaan mempunyai signifikansi sebesar $0.000<a$ maka dapat disimpukan $\mathrm{H}_{0}$ ditolah sehingga ukuran perusahaan berpengaruh signifikan secara positif terhadap struktur modal (LTD.ER)

\section{Uji Simultan (Uji F)}

Uji F digunakan untuk mengetahui pengaruh secara simulant antara variabel independen terhadap variabel dependen. Dalam penelitian ini berarti menguji pengaruh tangibility, profitability, liquidity, dan ukuran perusahaan secara simultan terhadap struktur modal perusahaan properti dan real estate yang terdaftar di ISSI periode 2015-2017.

Tabel 4.

Hasil Uji F

\begin{tabular}{|rc|c|c|c|c|c|}
\hline \multicolumn{2}{|c|}{ Model } & $\begin{array}{c}\text { Sum of } \\
\text { Squares }\end{array}$ & df & $\begin{array}{c}\text { Mean } \\
\text { Square }\end{array}$ & F & Sig. \\
\hline 1 Regression & 3.706 & 4 & .926 & 16.270 & $.000^{\mathrm{b}}$ \\
& $\begin{array}{r}\text { Residual } \\
\end{array}$ & 5.011 & 88 & .057 & & \\
& Total & 8.717 & 92 & & & \\
\hline
\end{tabular}

Sumber: Hasil Uji F (data diolah)

Berdasarkan hasil uji $\mathrm{F}$ yang tersaji pada tabel tersebut, maka dapat dinyatakan $\mathrm{H}_{0}$ ditolak atau $\mathrm{H}_{1}$ diterima dengan signifikansi 0.000 yang berarti kurang dari 0.05. Dengan hasil Uji F di atas maka dapat disimpulkan bahwa tangibility, profitability, liquidity, dan ukuran perusahaan memiliki pengaruh yang signifikan terhadap struktur modal.

\section{v. SIMPULAN}

Berdasarkan pembahasan hasil penelitian yang telah dilakukan maka simpulan yang dapat diambil adalah:

1. Tangibility memberikan pengaruh positif tidak signifikan terhadap struktur modal perusahaan properti dan real estate 
Ibrahim, et al/Jurnal Ekonomi Syariah Teori dan Terapan Vol. 6 N0. 5 Mei 2019: 977-992; FAKTOR-FAKTOR YANG MEMPENGARUHI STRUKTUR MODAL PADA PERUSAHAAN SEKTOR PROPERTI YANG TERDAFTAR DI INDEKS SAHAM SYARIAH INDONESIA (ISSI) PERIODE 2015-2017

yang terdaftar di Indeks Saham Syariah Indonesia (ISSI) periode 2015-2017, yang ditunjukkan oleh nilai signifikansi lebih dari 0.05 .

2. Profitability memberikan pengaruh negatif signifikan terhadap struktur modal perusahaan properti dan real estate yang terdaftar di Indeks Saham Syariah Indonesia (ISSI) periode 20152017, yang ditunjukkan oleh nilai signifikansi kurang dari 0.05 .

3. Liquidity memberikan pengaruh positif tidak signifikan terhadap struktur modal perusahaan properti dan real estate yang terdaftar di Indeks Saham Syariah Indonesia (ISSI) periode 2015-2017, yang ditunjukkan oleh nilai signifikansi lebih dari 0.05 .

4. Ukuran Perusahaan memberikan pengaruh positif signifikan terhadap struktur modal perusahaan properti dan real estate yang terdaftar di Indeks Saham Syariah Indonesia (ISSI) periode 2015-2017, yang ditunjukkan oleh nilai signifikansi kurang dari 0.05 .

5. Tangibility, profitability, liquidity, dan ukuran perusahaansecara simultan terbukti berpengaruh secara signifikan terhadap struktur modal perusahaan properti dan real estate yang terdaftar di Indeks Saham Syariah Indonesia (ISSI) periode 2015-2017, yang ditunjukkan oleh nilai signifikansi kurang dari 0.05.

\section{DAFTAR PUSTAKA}

Alwi, Syafaruddin. 1991. Alat-alat Analisis Dalam Pembelanjaan Edisi Revisi. Yogyakarta : Andi Offset.
Atmaja, Lukas Setia. 2003. Manajemen Kevangan. Yogyakarta : Andi Offset.

Brigham, Eugene dan Joel F. Houston. 2001. Manajemen Keuangan Buku 2. Jakarta : Erlangga.

Hadianto, Bram. 2010. Pengaruh Struktur Aktiva, Ukuran Perusahaan, dan Profitabilitas Terhadap Struktur Modal Emiten Sektor Telekomunikasi Periode 2000-2006: Sebuah Pengujian Hipotesis Pecking Order. Jurnal diterbitkan, Universitas Kristen Maranatha Bandung

Halim, Abdul. 2007. Manajemen Kevangan Bisnis. Bogor : Ghalia Indonesia

Harahap, Sofyan Syafri. 2009. Analisis Kritis atas Laporan Keuangan. Jakarta: Rajawali Pers

Harrison Jr., Walter T., et al. 2012. Akuntansi Keuangan International Financial Reporting Standards. Jakarta : Erlangga

Herlianto, Didit. 2013. Manajemen Investasi Plus Jurus Mendeteksi Investasi Bodong. Yogyakarta: Gosyen Publishing.

http://www.ojk.go.id/id/kanal/pasarmodal/Pages/Syariah.aspx

Kesuma, Ali. 2009. Analisis Faktor yang Mempengaruhi Struktur Modal Serta Pengaruhnya Terhadap Harga Saham Perusahaan Real Estate yang Go Public di Bursa Efek Indonesia. Jurnal, Universitas 
Ibrahim, et al/Jurnal Ekonomi Syariah Teori dan Terapan Vol. 6 N0. 5 Mei 2019: 977-992; FAKTOR-FAKTOR YANG MEMPENGARUHI STRUKTUR MODAL PADA PERUSAHAAN SEKTOR PROPERTI YANG TERDAFTAR DI INDEKS SAHAM SYARIAH INDONESIA (ISSI) PERIODE 2015-2017

Darwan Ali Sampit Kalimantan Tengah

Kementerian Agama Republik Indonesia. 2015. Al Quran Terjemahan. Jakarta: Kementerian Agama Republik Indonesia

Libby, Robert, et al. 2008. Akuntansi Keuangan. Yogyakarta: ANDI

Mauluda, Fina Rahmi. 2016. Faktor Faktor yang Mempengaruhi Rasio Hutang dan Pengaruhnya Terhadap Harga Saham Perusahaan yang Terdaftar di Jakarta Islamic Index (JII) Periode 2010-2014. Skripsi tidak diterbitkan, Universitas Airlangga

Myers, Stewart C. 2001. Capital Structure. The Journal of Economic Prespectives. Vol. 15, No. 02.

Nafarin, M. 2009. Penganggaran Perusahaan. Jakarta : Salemba Empat.

Naibaho, Okthaleon. 2012. Analisis Struktur Modal PT. $X$. Tesis diterbitkan, Universitas Indonesia.

Nisfiannoor, Muhammad. (2009). Pendekatan Statistika Modern. Jakarta: Salemba Humanika

Nugroho, Asih Suko. 2006. Analisis FaktorFaktor yang Mempengaruhi Struktur Modal Perusahaan Properti yang Go-Public di Bursa Efek Jakarta untuk Periode Tahun 19942004. Tesis diterbitkan, Universitas Diponegoro.

Pramono, Nindyo. 2013. Hukum PT Go Public dan Pasar Modal. Yogyakarta: Andi Offset.
Puji, Yulianti Dwi. 2016. Pengaruh Profitabilitas dan Likuiditas terhadap Struktur Modal dan Kebijakan Dividen yang Terdaftar di Jakarta Islamic Index (JII) Periode 2010-2014. Skripsi tidak diterbitkan, Universitas Airlangga.

Riyanto, Bambang. 2001. Dasar-dasar Pembelanjaan Perusahaan. Edisi 4.Yogyakarta : BPFE.

Samryn, L.M. 2012. Akuntansi Manajemen : Informasi untuk Mengendalikan Aktivitas Operasi dan Informasi. Jakarta : Kencana.

Sedarmayanti dan Syarifudin Hidayat. 2002. Metode Penelitian. Bandung : Mandar Maju.

Setyanto, Budi, dkk. 2006. Pengenalan Eksklusif:Ekonomi Islam. Jakarta : Prenada Media Group.

Sugiono, Arief. 2009. Manajemen Keuangan untuk Praktisi Keuangan. Jakarta: Grasindo.

Sutopo, Yeri dan Achmad Slamet. 2017. Statistik Inferensial. Yogyakarta : ANDI.

Wardhana, Guruh Hanityo. 2012. Pengaruh Profitability, Asset Tangibility, dan Institutional Ownership terhadap Struktur Modal dan Dampaknya pada Kebijakan Dividen (Studi pada Industri Manufaktur di Bursa Efek Indonesia Periode 2009-2011). Universitas Diponegoro. Jurnal Bisnis Strategi Vol 21 No 1. 
Ibrahim, et al/Jurnal Ekonomi Syariah Teori dan Terapan Vol. 6 N0. 5 Mei 2019: 977-992; FAKTOR-FAKTOR YANG MEMPENGARUHI STRUKTUR MODAL PADA PERUSAHAAN SEKTOR PROPERTI YANG TERDAFTAR DI INDEKS SAHAM SYARIAH INDONESIA (ISSI) PERIODE 2015-2017

Yoreno, Alfian Alib. 2014. Pengaruh Struktur Aset, Profitabilitas, Growth dan Size terhadap Struktur Modal (Studi Empiris pada Perusahaan Otomotif di Bursa Efek Indonesia). Skripsi diterbitkan. STIESIA. 